\title{
Analysis of the impact of water flow rate of selected Turbo type nozzle on the distribution of sprinkling intensity
}

\author{
Jerzy Gałaj ${ }^{1}$, Tomasz Drzymała ${ }^{2}$, Adam Pełech $^{3}$, Ritoldas Šukys ${ }^{4}$ \\ ${ }^{1-3}$ Faculty of Fire Safety Engineering, The Main School of Fire Service, Warsaw, Poland \\ ${ }^{4}$ Faculty of Labour Safety and Fire Protection, Vilnius Gediminas University, Vilnius, Lithuania \\ E-mail: ${ }^{1}$ jgalaj@sgsp.edu.pl (corresponding author)
}

\begin{abstract}
In the work, the distribution of the sprinkling intensity for a selected nozzle with the trade name Turbomatic was tested and analysed. The device meets Polish legal requirements, has a CNBOP approval certificate and is classified as a TURBO type nozzle. The research was aimed at extending the knowledge about spray jets generated by nozzles, in particular analysing the impact of water flow rate on selected parameters of the sprinkling surface. These dependencies can in practice save water and more effectively extinguish during rescue and firefighting operations. The tests were carried out in the laboratory of the Rescue and Fire-Fighting Equipment of the Main School of Fire Service partly in field conditions. Two different water flow rates of 200 and $400 \mathrm{dm}^{3} / \mathrm{min}$ were assumed at a set operating pressure at the nozzle outlet of $0.4 \mathrm{MPa}$. The position and methodology of conducted research was discussed. Selected results were presented in tabular and graphical form. Their analysis was carried out and conclusions were made based on it. They shows that the flow rate of the nozzle has a significant impact on sprinkling surface parameters such as: its size and shape, range projection, maximum value of sprinkling intensity, location of maximum, etc.
\end{abstract}

Keywords: sprinkling intensity, water nozzle, Turbo type nozzle, spraying surface, nozzle flow rate.

\section{Introduction}

The basic task carried out by firefighters all over the world is to combat with fires. The most common and the most effective extinguishing agent is still 'ordinary' water. Despite many advantages, water has some drawbacks and limitations. In certain situations extinguishing by water is even strongly prohibited. Therefore, it is a very important issue to apply water jets into fire and flames in a proper way. Water streams used during firefighting and rescue actions should be correctly formed and applied to maximize extinguishing efficiency (Kokot-Góra, 2015). In the 1950s it was observed that spray water streams have better extinguishing properties than solid jets (Braidech, Neale, Matson, \& Dufour, 1955). It has been proved that the level of usage of water in spray streams is very high and its influence on flames seems to be getting more effective (Mawhinney \& Richardson, 1996). Many theoretical and experimental studies conducted over the past dozen or so years have shown that sprayed streams are characterized by greater extinguishing efficiency than solid streams (Grimwood, 1992, 2002, 2005; Kokot-Góra, 2012, 2015; Mitosek, 2007; Orzechowski \& Prywer, 1991, 2008; Zarzycki \& Prywer, 2017; Zbrożek \& Prasuła, 2009; Włodarczak, 2016). In addition, in this case, a smaller amount of water is consumed with much lower fire losses caused by flooding. Nowadays researchers from all over the world are trying to solve the problem of optimization of extinguishing process using water. This clearly means that firefighting and rescue actions must be carried out to extinguish the fire as fast as possible using minimal required water together with causing as small as possible water damages (Kokot-Góra, 2015; Grimwood 2002, 2005). Therefore, in recent years, Turbo nozzles have been widely used in fire protection, which in addition to solid streams allow the generation of several types of the sprays with varying degrees of atomization (the maximum range of spraying angles ranges from $30^{\circ}$ to $120^{\circ}$ ). More recently, fog nozzles have been used more and more frequently, whose streams are characterized by even smaller average droplet diameters than standard Turbo nozzles. Because on the basis of the theory and experiments, it is known that the extinguishing efficiency depends primarily on sprinkling intensity and the average diameter of droplets. Experiments related to the study of spray streams produced by various types of Turbo nozzles (Hamid \& Atan, 2009; Huang, Wang, Jin, Liao, \& Qin, 2007; Huang, Wang, \& Liao, 2010; Konecki, Król, \& Wróblewski, 2003; Liang et al., 2015; Liu, Don, \& Kim, 2008; Wang, Liao, Qin, \& Fan, 2002) were carried out in the world, and in recent years in Poland. Among others, the influence of their construction and some parameters on the distribution of average droplet diameters was investigated (Gałaj \& Żurawski, 2014; Gałaj, Drzymała, \& Tabaka, 2016; Gałaj, Drzymała, \& Pełech, 2017a; Gałaj, Drzymała, \& Piątek, 2017b; Jakóbiec, 2016;

(C) 2019 Authors. Published by VGTU Press. This is an open-access article distributed under the terms of the Creative Commons Attribution (http://creativecommons.org/licenses/by/4.0/) License, which permits unrestricted use, distribution, and reproduction in any medium, provided the original author and source are credited. 
Kwas, 2017; Madzio, 2017; Pełech, 2017; Piątek, 2016, 2018; Ptak, 2017; Tabaka, 2016). Wide range of usage possibilities is their the biggest advantage.

The aim of this work is to evaluate the influence of such parameters of the Turbomatic nozzle as the flow rate and pressure on the distribution of sprinkling intensity. The following chapters discuss the subject, the measurement stand and the research methodology as well as present the results and their analysis. At the end of work the conclusions formulated on the analysis were included.

\section{Description of the tests}

\section{Subject of the study}

The subject of the research was the Turbomatic water nozzle produced by the Slovenian company JMW Fire. The device has the ability to adjust flow rate in the range of 100,200,300 and $400 \mathrm{dm}^{3} / \mathrm{min}$ and the function FLUSH, i.e. the possibility of rinsing contaminants. The ring has an increased precision of the expenditure setting due to the bearing system used (a characteristic "click" can be heard on individual performance values). The second rim on the head serves to change the spray angle. According to the catalog, it can generate three types of stream: solid, diffuse and a

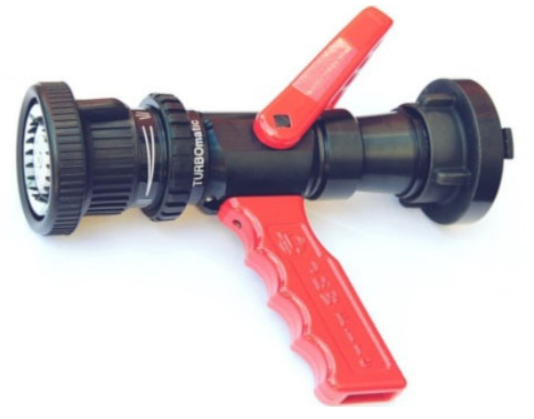
water umbrella (foggy) (Liang et al., 2015, Särdqvist, 2002). The weight of Turbomatic nozzle is $2.24 \mathrm{~kg}$ and the dimensions: $279 \mathrm{~mm}$ length, 244 width and $110 \mathrm{~mm}$ height. The device has a CNBOP approval certificate No. 1634/2013. An overlay can be mounted on the head that allows the production of a heavy class $\mathrm{S}-2$ (PP-2) foam stream. Impact resistance is provided by the rubber head. The nozzle is terminated with a storz connector to which a hose line can be connected. A view of Turbomatic nozzle is shown in Figure 1.

Figure 1. A view of Turbomatic nozzle

(https://kadimex.pl/produkt/pradownica-turbomatic)

\section{Description of the measurement stand}

Figure 2 presents the diagram of the test stand, along with the most important elements listed below:

1. A Turbo type nozzle with a tripod that maintains an angle of $15^{\circ}$ according to the standards.

2. Tensometric pressure transducer.

3. Electromagnetic flowmeter.

4. A set of three pumps with tanks with a total capacity of $3 \mathrm{~m}^{3}$.

5. External hydrant.

6. Set of electronic devices (control cabinet, anemometer, measuring scale) connected to a PC.

7. The measurement containers.

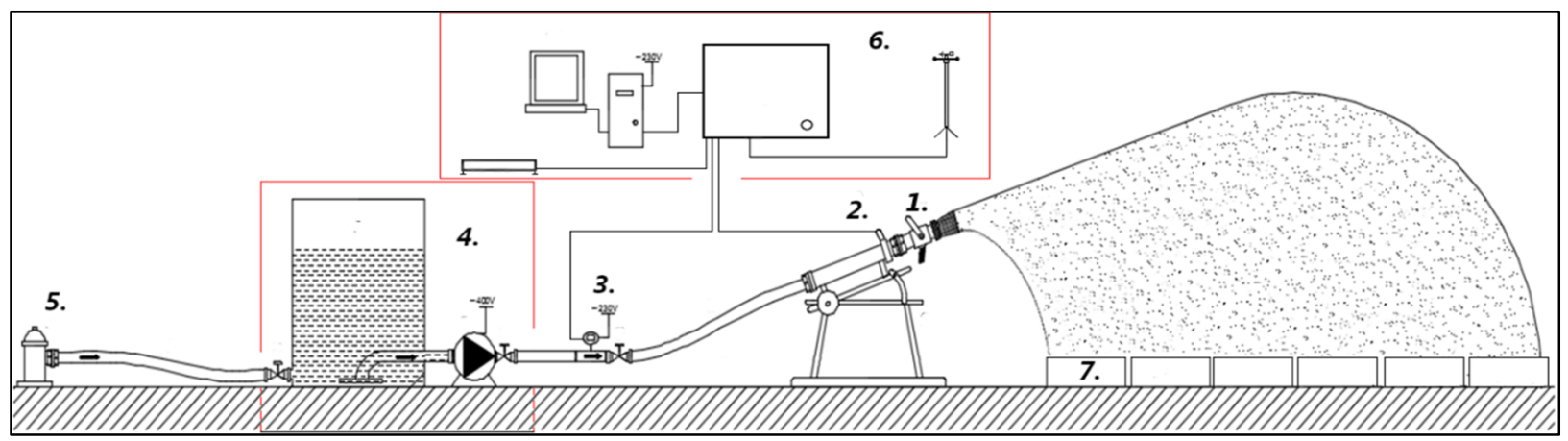

Figure 2. Simplified schema of the test stand

The tripod consisted of two parts, the base and the pipe. The Turbomatic nozzle was mounted to a pipe in which two side were terminated by storz connectors with a diameter $52 \mathrm{~mm}$. From the top, pressure gauges were installed in the body, electric and mechanical. The angle of inclination of the base relative to the ground during the whole research period was set at $15^{\circ}$ (PN-EN 13565-1 + A1: 2010 requirements and test methods for components). The measurement range of piezoelectric transducer of the pressure was $0-1$ MPa with an accuracy of $\pm 0.5 \%$. The signal from the device in real time (every 1s) was converted in the transmitter to the pressure value and then sent to the computer and saved 
in a spreadsheet. A mechanical pressure gauge was used to compare of both indications. Figure 3 shows the view of the nozzle attached to the frame.

Flowmeter MTF-10 DN50 was used to measure the volumetric flow rate. The device consisted of an electromagnetic pulse transducer, display and a measuring sensor. The LCD screen shows the current flow of liquid, given in $\mathrm{dm}^{3} /$ min with an accuracy of $0.5 \%$. The piezoelectric sensor is located in the tube, while the transducer with the microprocessor controls in the housing on which the LCD display is installed. Flow data was sent to the computer every 1 second. A mushroom valve was used to adjust the water flow rate. The system was supplied from a set of three Grundfos pumps model CR 8-80 A-A-BUBE model B42500008 PL 9544 and two tanks with a capacity of $2 \times 1.5 \mathrm{~m}^{3}$. The nominal parameters of the system work is $9.5 \mathrm{~m}^{3} / \mathrm{h}$ at a rotation speed of 2,900 rpm and a lifting height of approx. $70 \mathrm{~m}$. Due to the large amount of water necessary for the measurements, the system was filled from an external water source (external hydrant). To determine the sprinkling intensity in the tests, it was necessary to measure the mass of the liquid. For this purpose, the laboratory scale WLC $60 / \mathrm{C} 2 / \mathrm{K}$, manufactured by RADWAG, was used. The maximum load of the device is $60 \mathrm{~kg}$ and its accuracy is $1 \mathrm{~g}$. The stabilization time of the measurement result was $3 \mathrm{~s}$. Figure 4 shows the view of the laboratory scale used during the tests. The Bosch GLM 150 Professional laser rangefinder was used to measure the length of the projection and the distance between the containers. The measurement accuracy of the device is up to $1 \mathrm{~mm}$. During the study there were changes in atmospheric conditions. Changes in wind direction and velocity were recorded by the LB-747 anemometer manufactured by Lab-EL. The results of measurements from the flowmeter, manometer and anemometer were sent in real time to the cabinet with relays, which in turn was connected to the computer station, to which all measurement data received from the meters were sent on an ongoing basis. Figure 5 shows the view of the computer station. Specially developed software SGSP Measurements, enabled reading, editing and saving was applied. In the main window of the program there are panels that allow to calculate the sprinkling intensity, determine the flow rate of the nozzle, as well as import the sizes of average diameters of droplets obtained from another measuring system. All quantities are exported to MS Excel files. Figure 6 shows the main window of the SGSP Measurement program. Firstly, the surface area on which water jets were falling was determined. Then the size of the resulting ellipse was estimated and the matrix was prepared on the square. The container matrix facilitated the work of arranging them, because the spraying surface changed each time when the efficiency was changed. Containers were placed on the matrix prepared on sprinkling surface (Figure 7). Sample distribution of containers during the test is shown in Figure 8. The pump system was started and the valve was opened on the nozzle. Pressure and efficiency stabilized for a few seconds to finally reach the assumed values. At the same time when the valve on the nozzle was opened, another participant of the tests started the „START" button in the SGSP Measurement program. The tests were carried out to fill the container with the largest amount of water in about $3 / 4$ of the volume. Then the valve was closed on the nozzle and the saving of data were stopped by pressing the „STOP“ button in the program. Each container was placed on the scale and its weight was recorded. Each time, the scale was calibrated to obtain more accurate results.

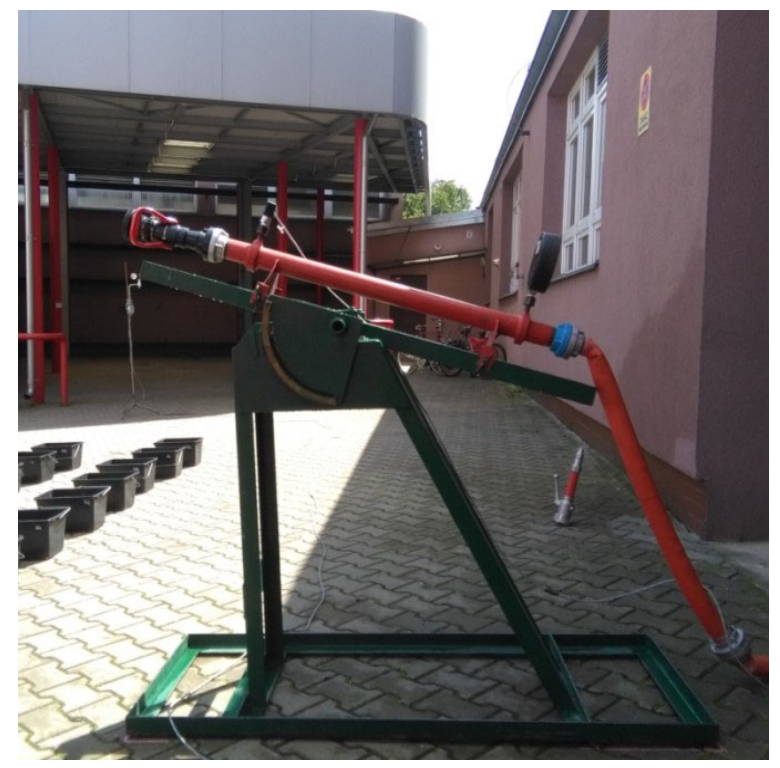

Figure 3. A view of the frame with Turbomatic nozzle attached

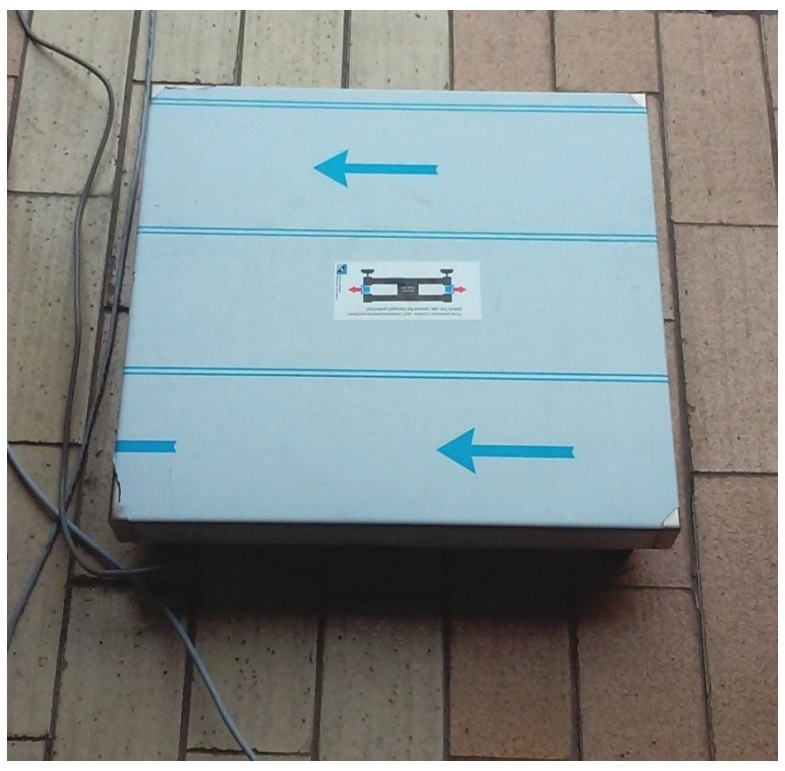

Figure 4. A view of laboratory scale 


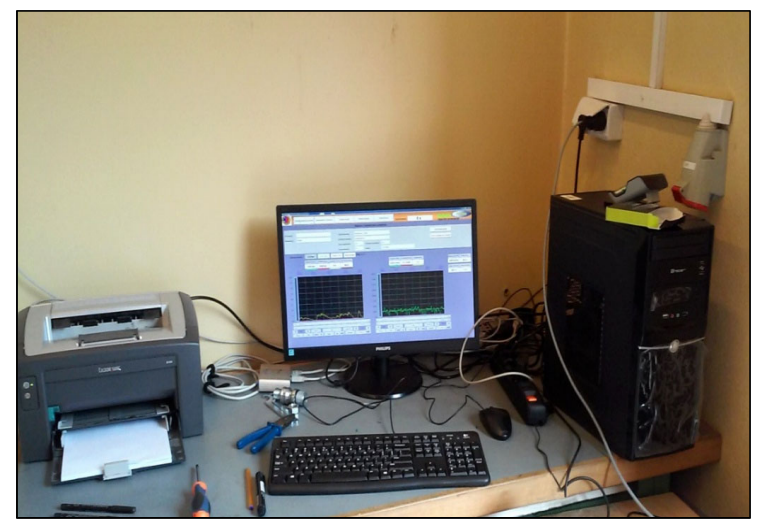

Figure 5. A view of computer station

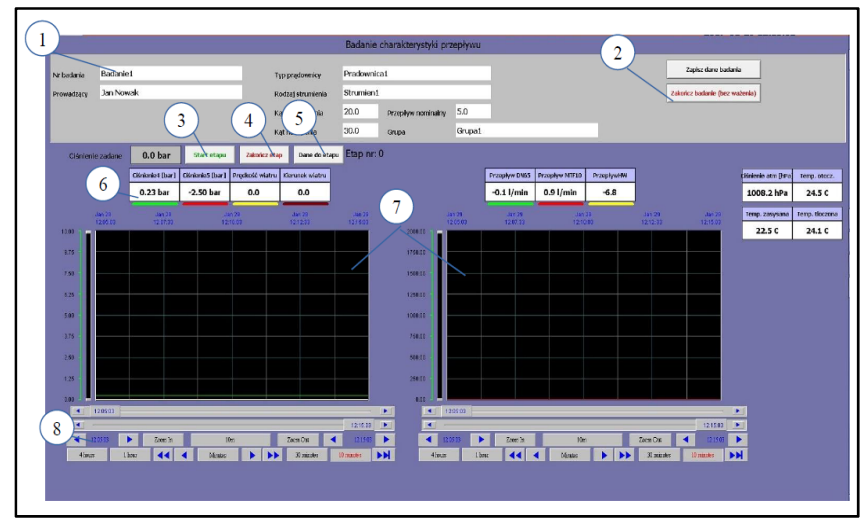

Figure 6. A view of the main window of the program SGSP Measurement (1 - Input data section; 2 - Test end button; 3 - Test start button; 6 - Preview of sensor indications; 7 - sensor indications diagrams section)

\section{Description of the measurement procedure}

The order of the activities performed during the tests was as follows:

1. Starting the PC and the pump controller.

2. Starting and entering parameters in the SGSP Measurement program.

3. Setting the specified pressure/flow rate of $200 \mathrm{dm}^{3} / \mathrm{min}$ and $0.4 \mathrm{MPa}$.

4. Determination of the size of the ellipse formed after spraying.

5. Placement of containers on the square.

6. Turning the pump set on.

7. Open the valve on the nozzle and click on the START button at the same time.

8. Closing the valve on the nozzle when the first tank is filled in about $75 \%$.

9. Clicking the STOP button.

10. Switching off the pumps.

11. Tare weight.

12. Weigh all containers and record individual masses of liquids according to the arrangement on the matrix in the program.

13. Saving the results of a single test.

14. Repetition of particular activities from 2 to 13 , for a flow rate of $400 \mathrm{dm}^{3} / \mathrm{min}$.

15. Switching off the PC and pump controller.

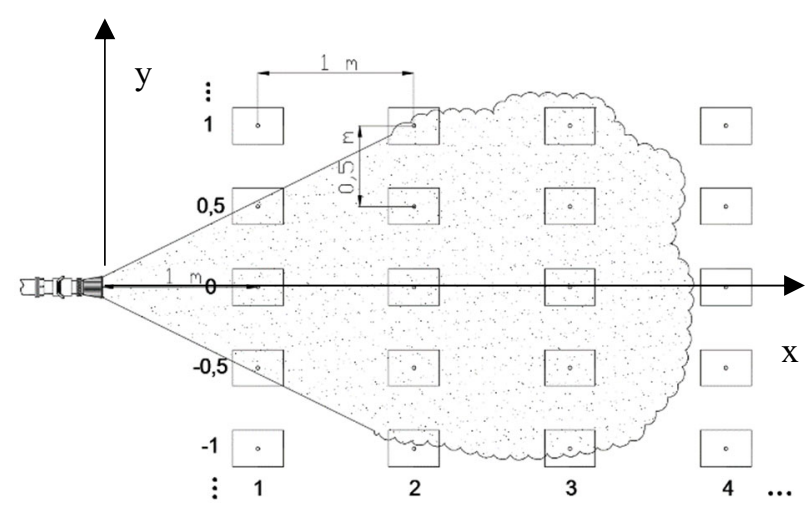

Figure 7. A scheme of arrangement of measuring containers

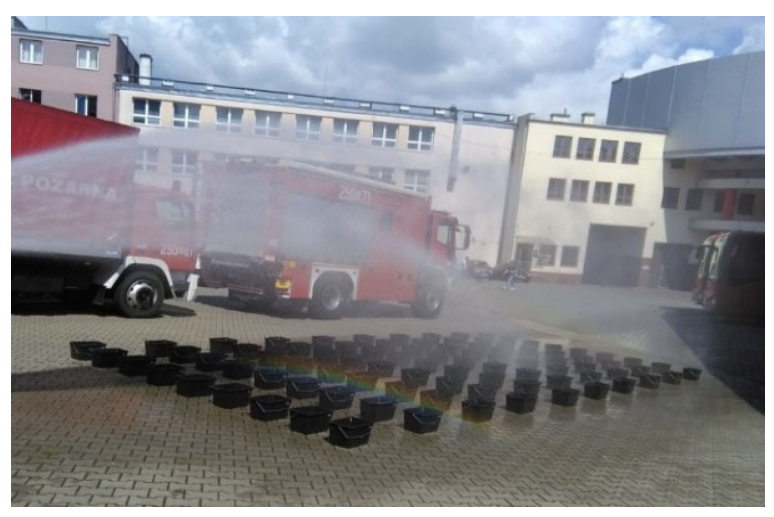

Figure 8. A view of exemplary arrangement of measuring containers

The mathematical definition of sprinkling intensity is represented by formula (1). The result recorded in this form is the volume of water spraying the surface of one square meter for one minute. The surface of the spraying was the area of the measuring container.

$$
\mathbf{I}_{\mathbf{z}}=\frac{\mathbf{V}_{\mathbf{c}}}{\mathbf{F} \cdot \mathbf{t}}[\mathrm{mm} / \mathrm{min}]
$$

where: $V_{c}$-volume of water in container $\left[\mathrm{mm}^{3}\right] ; F-$ container area $\left[\mathrm{mm}^{2}\right] ; t-$ measurement time $[\mathrm{min}]$. 
The mass of water in the containers after the test was converted into a volume $V_{c}$. For this purpose, the liquid temperature recorded during the measurements was used, thanks to which the water density was read from the dependence table (temperature/density). The value obtained was used in the formula (2). It was also necessary to change the unit from $\mathrm{m}^{3}$ to $\mathrm{mm}^{3}$.

$$
\mathbf{V}_{\mathbf{c}}=\frac{\mathbf{m}}{\boldsymbol{\rho}}\left[\mathrm{mm}^{3}\right]
$$

\section{Results}

In this section, results obtained during tests at the following parameters: pressure $0,4 \mathrm{MPa}$, medium spray and two different flow rates of the nozzle 200 and $400 \mathrm{dm}^{3} / \mathrm{min}$ are included. Three-dimensional distributions of sprinkling intensity, layers of the distribution and longitudinal section section along the plain containing maximum of sprinkling intensity at flow rates of 200 and $400 \mathrm{dm}^{3} / \mathrm{min}$ are presented in the Figures 9-14. The analysis of the distribution of the sprinkling intensity was carried out on the basis of the following criteria: sprinkling area, maximum of sprinkling intensity and maximum range of water jet. In addition, the coordinates of the point on the surface where the maximum sprinkling intensity was calculated were taken into account. For comparison purposes, values of aforementioned quantities, for two tested flow rates are included in Table 1. Table 1 shows that with twice the flow rate, all analyzed parameters have increased significantly from one and a half times in the case of a throw range to more than twice in the case of the maximum sprinkling intensity. In addition, in the case of higher flow rate, the shape of the sprinkling surface is more elongated (with the same length of the lateral axis equal to about $5 \mathrm{~m}$, the length of the longitudinal axis is about 4 m higher).

Table 1. Characteristic parameters of spraying surface for pressure $0.4 \mathrm{MPa}$, medium spray and two different flow rates

\begin{tabular}{|c|c|c|c|c|c|c|}
\hline No & $\begin{array}{c}\text { Flow rate } \\
{[\mathrm{dm} 3 / \mathrm{min}]}\end{array}$ & $\begin{array}{c}\text { Sprinkling } \\
\text { area } \\
{[\mathrm{m} 2]}\end{array}$ & $\begin{array}{c}\text { Maximum length/width } \\
\text { of spraying surface } \\
{[\mathrm{m}]}\end{array}$ & $\begin{array}{c}\text { Maximum sprinkling } \\
\text { intensity } \\
{[\mathrm{mm} / \mathrm{min}]}\end{array}$ & $\begin{array}{c}\text { Coordinates of } \\
\text { maximum point } \\
\text { (x,y) }[\mathrm{m}]\end{array}$ & $\begin{array}{c}\text { Maximum range } \\
\text { of water jet } \\
{[\mathrm{m}]}\end{array}$ \\
\hline 1 & 200 & 25 & $8 / 5$ & 12 & $6,-1$ & 10.3 \\
2 & 400 & 40 & $12 / 5$ & 26 & 8,0 & 15.0 \\
\hline
\end{tabular}

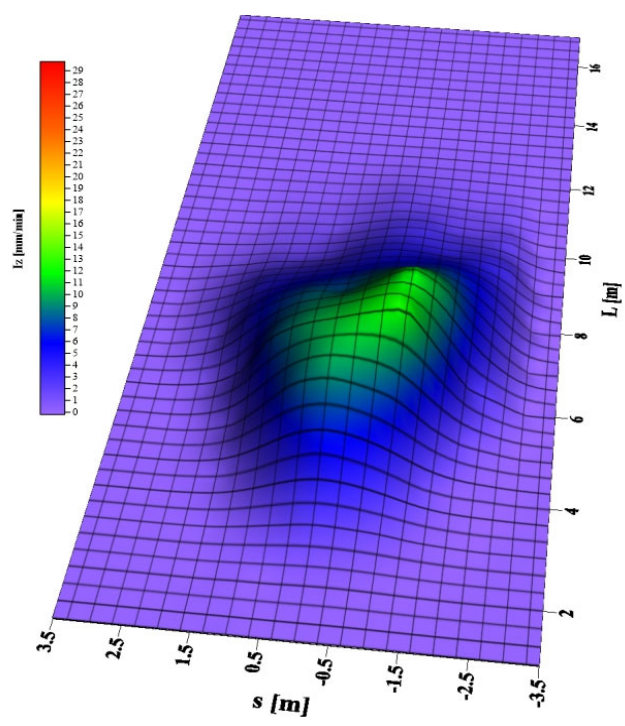

Figure 9. Three-dimensional distribution of sprinkling intensity at flow rate of $200 \mathrm{dm}^{3} / \mathrm{min}$

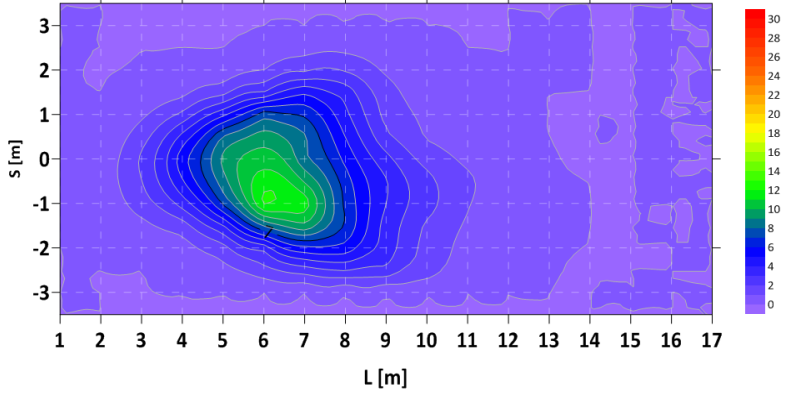

Figure 10. Layers of sprinkling intensity distribution at flow rate $200 \mathrm{dm}^{3} / \mathrm{min}$

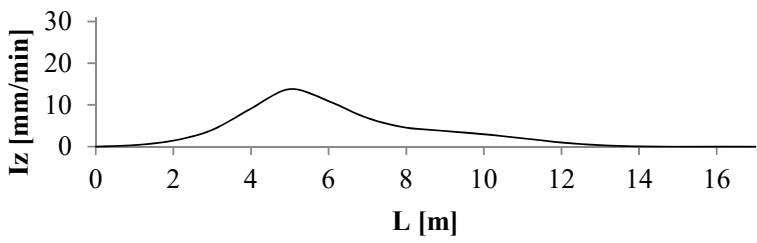

Figure 11. Longitudinal section along the plain containing maximum of sprinkling intensity at flow rate of $200 \mathrm{dm}^{3} / \mathrm{min}$ 


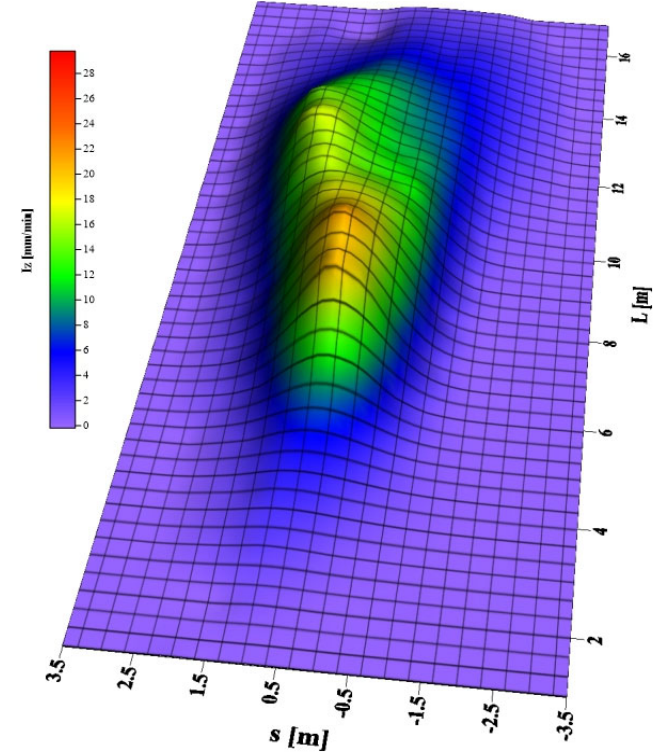

Figure 12. Three-dimensional distribution of sprinkling of intensity at flow rate of $400 \mathrm{dm}^{3} / \mathrm{min}$

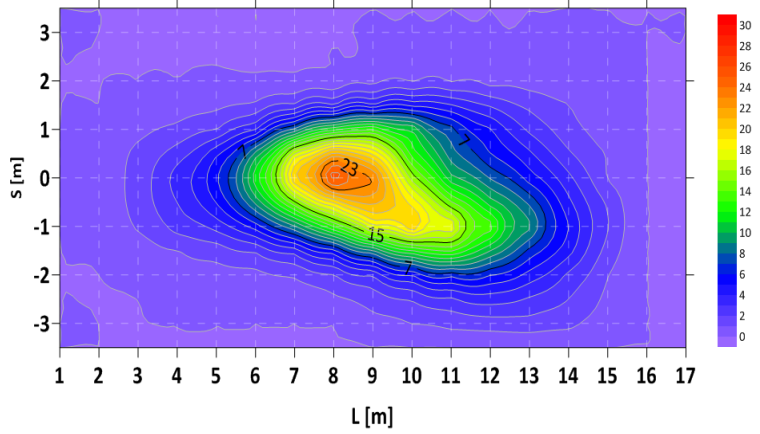

Figure 13. Layers of sprinkling intensity distribution at flow rate $400 \mathrm{dm}^{3} / \mathrm{min}$

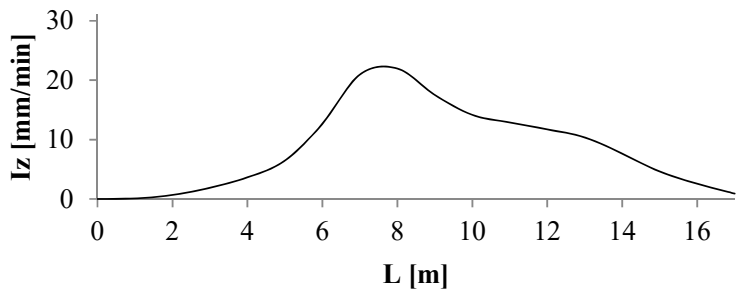

Figure 14. Longitudinal section along the plain containing maximum intensity at flow rate of $400 \mathrm{dm}^{3} / \mathrm{min}$

\section{Conclusions}

As a result of the conducted measurements, the distribution of the sprinkling intensity using the spray generated by the tested Turbomatic nozzle were obtained. The tests were carried out at pressure of $0.4 \mathrm{MPa}$, medium spray (set on the head of the nozzle) and two different water flow rates of $200 \mathrm{dm}^{3} / \mathrm{min}$ and $400 \mathrm{dm}^{3} / \mathrm{min}$. The tests took place in polygon conditions, so the atmospheric factors also influenced the results. It was attempted to choose the maximum windless days, but it was not always possible. In addition, local turbulence was also created, which affected the results obtained and, above all, stream symmetry. In the case of excessive deviations, the measurements were repeated. On the basis of the results obtained teh following conclusions have been formulated:

1. At higher flow rate $\left(400 \mathrm{dm}^{3} / \mathrm{min}\right)$ a larger sprinkling area equal to $40 \mathrm{~m}^{2}$ than at $200 \mathrm{dm}^{3} / \mathrm{min}\left(25 \mathrm{~m}^{2}\right)$ was obtained.

2. The higher sprinkling intensity of $25.97 \mathrm{~mm} / \mathrm{min}$ was obtained at higher flow rate of $400 \mathrm{dm}^{3} / \mathrm{min}$ in comparison with $12 \mathrm{~mm} / \mathrm{min}$ received at flow rate of $200 \mathrm{dm}^{3} / \mathrm{min}$.

3. The maximum range of the spray jet produced by the Turbomatic nozzle $(15 \mathrm{~m})$ was about $50 \%$ higher at flow rate of $400 \mathrm{dm}^{3} / \mathrm{min}$ then at $200 \mathrm{dm}^{3} / \mathrm{min}(10.3 \mathrm{~m})$.

4. The point corresponding to the maximum value of the sprinkling intensity was located about $2 \mathrm{~m}$ away from the nozzle for a flow rate of $400 \mathrm{dm}^{3} / \mathrm{min}$ (approximately $8 \mathrm{~m}$ ) than for $200 \mathrm{dm}^{3} / \mathrm{min}$ (approximately $6 \mathrm{~m}$ ). The deviation of this point from the central axis in the case of lower flow rate could have been caused by gusts of wind whose average speed was about $1 \mathrm{~m} / \mathrm{s}$.

5. The length of spraying surface obtained at flow rate of $200 \mathrm{dm}^{3} / \mathrm{min}$ was about $4 \mathrm{~m}$ shorter than obtained at $400 \mathrm{dm}^{3} / \mathrm{min}$ while the width of them were comparable (about $5 \mathrm{~m}$ ).

In summary, the work is an assessment of the impact of flow rate on the sprinkling intensity. The focus was only on medium spray jets and pressure, due to the fact that they are more often used in firefighting activities. Carrying out the tests for different pressures, water spray level and other type of nozzles are planned in the future. Certainly, it would broaden the knowledge about the quality of the jets being produced by the nozzles, which would contribute to their extinguishing effectiveness.

\section{References}

Braidech, M. M., Neale, J. A., Matson, A. F., \& Dufour, R. E. (1955). The mechanism of extinguishment of fire by finely divided water. Underwriters' laboratories. New York.

Gałaj, J., Drzymała, T., \& Pełech, A. (2017a). Analiza rozkładu intensywności zraszania wybranej prądownicy wodnej. BUSES, Technology, Operation and Transport Systems, 12, 873-879 (in Polish). 
Gałaj, J., Drzymała, T., \& Piątek, P. (2017b). Analysis of influence of tilt angle on the distribution of water droplets diameters in a spray generated by the Turbo Master 52 nozzle. Procedia Engineering, 172, 300-309. https://doi.org/10.1016/j.proeng.2017.02.118

Gałaj, J., Drzymała, T., \& Tabaka, D. (2016). Analiza wpływu wydajności i kąta rozpylenia na rozkład średnic kropel w strumieniu rozpylonym wytwarzanym przez prądownicę Turbo Master 52. Fire Safety and Technique, 43(3), 51-62 (in Polish).

Gałaj, J., \& Żurawski, Ł. (2014). Some approach to upper cooling process with spray stream generated by water nozzle using computer simulation method. Transactions of the VSB - Technical University of Ostrava, 9(1), 1-9. https://doi.org/10.2478/tvsbses-2014-0001

Grimwood, P. (2002). Flashover \& nozzle techniques. Crisis \& Emergency Managment Centre (CEMAC).

Grimwood, P. T. (1992). Fog attack firefighting strategy \& tactics - An international. FMJ International Publication Ltd. Sweden. Grimwood, P. T. (2005). Fire-fighting flow-rate. Barnett (NZ) Grimwood (UK) Formulae, b.m.w.

Guzewski, P., Wróblewski, D., \& Małozięć, D. (red.) (2016). Czerwona księga pożarów. Wybrane problemy pożarów oraz ich skutków. Tom 2, Józefów (in Polish).

Hamid, A. H. A., \& Atan, R. (2009). Spray characteristics of jet-swirl nozzles for thrust chamber injector. Aerospace Science and Technology, 13(4-5), 192-196. https://doi.org/10.1016/j.ast.2008.10.003

Huang, X., Wang, X. S., Jin, X., Liao, G. X., \& Qin, J. (2007). Fire protection of heritage structures: use of a portable water mist system under high-altitude conditions. Journal of Fire Sciences, 25, 217-239. https://doi.org/10.1177/0734904107069675

Huang, X., Wang, X. S., \& Liao, G. X. (2010). Characterization of an effervescent atomization water mist nozzle and its fire suppression tests. Proceedings of the Combustion Institute, 33, 2573-2579. https://doi.org/10.1016/j.proci.2010.06.001

Jakóbiec, B. (2016). Analiza wpływu kąta rozpylenia na rozkład średnic kropel i intensywność zraszania w strumieniu rozpylonym wytwarzanym przez pradownice TURBO MASTER 52 (Master thesis of SGSP). Warszawa (in Polish).

Kokot-Góra, S. (2015). Techniki operowania prądami gaśniczymi. Air Press, Opole (in Polish).

Kokot-Góra, Sz. (2012). Compartment fire behaviour training 2012, czyli „O pożarach wewnętrznych po nowemu”. Olsztyn (in Polish).

Konecki, M., Król, B., \& Wróblewski, D. (2003). Nowoczesne metody działań ratowniczo-gaśniczych. SGSP Publishing House, Warsaw (in Polish).

Kwas, P. (2017). Analiza skuteczności gaśniczej dyszy mgłowej TF6 firmy bete na podstawie rozkładu temperatury w pomieszczeniu zamkniętym podczas gaszenia stosu drewna (Master thesis). Warsaw (in Polish).

Liang, T., Liu, M., Liu, Z., Zhong, W., Xiao, X., \& Lo, S. (2015). A study of probability distribution of pool fire extinguishing times using water mist. Process Safety and Environmental Protection, 93, 240-248. https://doi.org/10.1016/j.psep.2014.05.009

Liu, Z. G., Don, C., \& Kim, A. K. (2008). Cooling characteristics of hot oil pool by water mist during fire suppression. Fire Safety Journal, 43, 269-281. https://doi.org/10.1016/j.firesaf.2007.08.004

Madzio, S. (2017). Analiza rozkładu intensywności zraszania wybranej lancy gaśniczej (Master thesis of SGSP). Warsaw (in polish).

Mawhinney, J. R., \& Richardson, J. K. (1996). A review of water mist fire suppression research and development. Fire Technology, 33, 54-90. https://doi.org/10.1023/A:1015322428719

Mitosek, M. (2007). Mechanika płynów w inżynierii i ochronie środowiska. wyd. II, OWPW, Warsaw (in Polish).

Orzechowski, Z., \& Prywer, J. (1991). Rozpylanie cieczy. wyd. II. WNT, Warsaw (in Polish).

Orzechowski, Z., \& Prywer, J. (2008). Wytwarzanie i zastosowanie rozpylonej cieczy. WNT, Warsaw (in Polish).

Pełech, A. (2017). Analiza rozktadu intensywności zraszania wybranej pradownicy Blue Devil (Engineering diploma thesis of SGSP). Warsaw (in Polish).

Piątek, P. (2016). Analiza wplywu kąta pochylenia prądownicy na rozkład średnic kropel w strumieniu rozpylonym wytwarzanym przez pradownice Turbo Master 52 (Engineering diploma thesis of SGSP). Warsaw (in Polish).

Piątek, P. (2018). Analiza porównawcza wpływu kąta rozpylenia na rozkład intensywności zraszania w strumieniu rozpylonym wytwarzanym przez wybrane prądownice (Master thesis of SGSP). Warsaw (in Polish).

Placek, P. (2011). Sprzęt i armatura wodna. wyd. I, EDURA Publishing House, Warsaw (in Polish).

Ptak, M. (2017). Analiza wpływu kąta rozpylenia na rozkład intensywności zraszania pradownicy Blue Devil (Master thesis of SGSP). Warsaw (in Polish).

Särdqvist, S. (2002). Water and other extinguishing agents. Elanders NRS Tryckeri AB, Karlstad.

Tabaka, D. (2016). Analiza wplywu wydajności na rozktad średnic kropel i intensywność zraszania w strumieniu rozpylonym wytwarzanym przez pradownice TURBO MASTER 52 (Master thesis of SGSP). Warsaw (in Polish).

Turbomatic nozzle. (n.d.). Retrieved from https://kadimex.pl/produkt/pradownica-turbomatic

Wang, X. S., Liao, G. X., Qin, J., \& Fan, W. C. (2002). Experimental study on effectiveness of the extinction of a pool fire with water mist. Journal of Fire Sciences, 20(4), 279-295. https://doi.org/10.1177/073490402762574730

Włodarczak, S. (2016). Analiza hydrodynamiki w rozpylaczach wirowych (Dissertation). Poznań (in Polish).

Zarzycki, R., \& Prywer, J. (2017). Techniczna mechanika płynów. Wydawnictwo Naukowe PWN, Warsaw (in Polish).

Zbrożek, P., \& Prasuła, J. (2009). Wpływ wielkości średnic kropli mgły wodnej na efektywność tłumienia pożarów i chłodzenie. Fire Safety and Technique, 15, 113-148 (in Polish) 